\title{
Hyper-heuristics untuk Penyelesaian Masalah Optimasi Lintas Domain dengan Seleksi Heuristik berdasarkan Variable Neighborhood Search
}

\author{
Nisa Dwi Angresti*, Arif Djunaidy, Ahmad Muklason \\ Departemen Sistem Informasi \\ Institut Teknologi Sepuluh Nopember \\ Surabaya \\ *nisa.dwi.angresti@gmail.com
}

\begin{abstract}
Abstrak-Metode state-of-the-art untuk menyelesaikan permasalahan optimasi kombinatorik yang diketahui sebagai permasalahan non-deterministic polynomial hard (NP-hard) adalah meta-heuristics. Kelemahan dari metode meta-heuristics adalah dibutuhkanya parameter tuning yang spesifik untuk setiap problem domain berbeda. Hal ini menyebabkan pendekatan meta-beuristics kurang efektif untuk menyelesaikan permasalahan lintas problem domain. Untuk mengatasi permasalahan tersebut, muncul pendekatan baru, yaitu hyper-beuristics. Dengan meningkatkan level search space dari solution space ke low-level heuristics space, hyper-heuristics diharapkan dapat menjadi pendekatan yang lebih general dan efektif untuk menyelesaikan permasalahan lintas problem domain. Penelitian ini bertujuan untuk menginvestigasi performa algoritma variable neighborhood search (VNS) sebagai strategi untuk memilih low-level beuristics dalam kerangka kerja byper-heuristics. Hal ini berbeda dengan penelitian-penelitian sebelumnya di mana VNS digunakan dalam kerangka kerja meta-beuristics. Metode yang diusulkan dalam penelitian ini diuji coba pada 6 problem domain yang berbeda, yaitu satisfiability (SAT), one dimensional bin packing, permutation flow shop, personel scheduling, travelling salesman problem (TSP), dan vehicle routing problem (VRP). Hasil komputasi menunjukkan bahwa metode VNS ini memiliki performa lebih baik dibandingkan dengan metode seleksi low-level heuristics pembanding, yaitu Simple Random. Secara lebih spesifik, VNS lebih unggul pada 5 dari 6 problem domain.
\end{abstract}

Kata kunci: Optimasi Lintas Domain; Hyper-heuristics; Variable Neighborhood Search

\section{Pendahuluan}

Permasalahan optimasi kombinatorik adalah proses mencari satu solusi yang paling optimal dari kumpulan solusi yang tersedia [1]. Model optimasi kombinatorik berfungsi untuk memodelkan berbagai bentuk masalah dalam beberapa fungsi tujuan yang menunjukkan kualitas solusi yang diberikan, kemudian menggunakan algoritma pencarian tertentu untuk meminimalkan atau memaksimalkan fungsi tujuan tersebut [2]. Optimasi penting digunakan untuk membantu pengambilan keputusan dalam berbagai bidang, seperti bidang industri, pemerintahan, pendidikan, dan transportasi.

Permasalahan optimasi saat ini berkembang menjadi permasalahan yang kompleks karena banyaknya jumlah input dataset dan batasan yang harus dipenuhi dalam menentukan optimalitas. Beragam bentuk masalah optimasi kombinatorik berkembang pada berbagai bidang, di antaranya adalah masalah mengoptimalkan pengemasan barang, penjadwalan mesin, penjadwalan mata kuliah, dan penentuan rute kendaraan. Sebuah organisasi dapat membutuhkan banyak optimasi untuk mendukung bisnisnya. Sebagai contoh perusahaan yang bergerak dalam bidang logistik, tidak hanya membutuhkan optimasi untuk satu bidang, tetapi membutuhkan optimasi untuk banyak bidang, seperti penjadwalan sopir, rute kendaraan, dan pengemasan barang (bin packing) sekaligus.
Dalam mencari solusi optimal dibutuhkan berbagai jenis metode atau algoritma pencarian. Semakin banyaknya masalah optimasi, maka semakin banyak metode pencarian yang dikembangkan untuk menyelesaikan masalah tersebut. Secara garis besar, metode atau algoritma pencarian dalam menyelesaikan masalah optimasi dapat dikelompokkan menjadi dua kelompok, yaitu algoritma exact dan algoritma approximate [3] Algoritma exact digunakan untuk menyelesaikan masalah optimasi yang sederhana. Dalam menyelesaikan masalah sederhana, algoritma exact dapat menemukan solusi yang paling optimal dengan waktu yang cepat. Namun, pada masalah optimasi yang kompleks seperti permasalahan Traveling Salesman Problem (TSP), Vebicle Routing Problem (VRP), dan penjadwalan dengan input dataset yang besar, algoritma exact belum mampu mencari solusi yang paling optimal dalam running time yang cepat. Oleh karena itu, algoritma approximate seperti heuristics, meta-heuristics, dan byper-heuristik digunakan sebagai pilihan dalam menyelesaikan masalah optimasi yang kompleks. Algoritma approximate lebih mengutamakan pencarian yang cepat daripada pencarian yang lengkap, yakni exhaustive search sehingga efisien. Namun, solusi yang ditemukan dengan metode tersebut bukanlah solusi yang paling optimal, tetapi cukup baik dan dapat diselesaikan dengan waktu yang singkat, yakni polynomial time. 
Pengembangan metode heuristics adalah metaheuristics yang menyelesaikan masalah optimasi secara spesifik berdasarkan karakteristik satu permasalahan tertentu [4]. Untuk menyelesaikan banyak masalah optimasi, meta-heuristics harus mendeskripsikan dan memodelkan setiap permasalahan, serta menentukan metode pencarian yang tepat untuk menyelesaikan setiap masalah. Penyelesaian masalah optimasi secara spesifik membutuhkan biaya yang mahal dan waktu yang lama, karena jika ada masalah optimasi baru, metode tersebut harus memodelkan masalah dan memodifikasi metode pencarian dari awal serta diperlukan penentuan parameter tuning untuk setiap masalah. Penerapan metode tersebut dapat memperlambat proses pengambilan keputusan untuk mengoptimasikan banyak permasalahan yang berbeda (lintas domain). Oleh karena itu, perlu suatu metode yang dapat menyelesaikan berbagai masalah optimasi secara general sehingga dapat mempercepat pencarian solusi [5]

Hyper-heuristics adalah metodologi otomatis untuk mencari atau membuat heuristic baru dalam meningkatkan generalitas permasalahan dan instance dataset berbagai permasalahan optimasi yang kompleks [4]. Dalam menyelesaikan berbagai permasalahan optimasi, hyperheuristics memiliki dua tingkatan proses, yaitu high level heuristic dan low level heuristic (LLH). Hyper-heuristics merupakan high level heuristic yang melakukan manipulasi terhadap LLH yang terdapat pada setiap masalah spesifik. LLH merupakan heuristics yang melakukan pencarian solusi pada domain masalah optimasi. Proses pencarian yang bertingkat ini menjadi kerangka hyper-heuristics dalam meningkatkan generalitas permasalahan optimasi.

Walaupun hyper-heuristics dapat meningkatkan generalitas pencarian pada banyak permasalahan optimasi, tetapi kinerja hyper-heuristics dalam menemukan solusi optimal tidak selalu baik untuk semua permasalahan optimasi [5]. Hal tersebut disebabkan oleh perbedaan karakteristik permasalahan optimasi. Perbedaan karakteristik ini menyebabkan LLH pada setiap permasalahan optimasi juga berbeda-beda. Kinerja hyperheuristics masih harus ditingkatkan untuk menciptakan hasil yang lebih optimal. High level heuristic harus mengenali dan memanfaatkan LLH yang berbeda pada setiap permasalahan optimasi agar dapat menghasilkan solusi yang baik lebih optimal. High level heuristic memiliki dua mekanisme utama, yaitu mekanisme seleksi LLH dan move acceptance. Mekanisme seleksi LLH berfungsi untuk menemukan LLH yang diaplikasikan dalam menghasilkan solusi baru, sedangkan mekanisme move acceptance berfungsi untuk memutuskan apakah akan menerima solusi yang dihasilkan oleh LLH tersebut atau tidak [6]. Pencarian yang dilakukan di dalam proses tersebut harus menemukan optimalitas secara global. Mekanisme seleksi LLH dan move acceptance pada strategi seleksi high level heuristic ini dilakukan secara terpisah. Kombinasi dari kedua mekanisme ini menjadi strategi high level heuristic untuk meningkatkan kinerja dalam menemukan solusi optimal pada berbagai permasalahan optimasi.
Penerapan hyper-heuristics telah dilakukan pada penelitian sebelumnya. Dalam penelitian [7] diusulkan strategi high level heuristic menggunakan metode simple random yang dikombinasikan dengan metode adaptive iteration limited list-based threshold Acceptance. Penelitian [8] mengusulkan strategi high level heuristic menggunakan metode simple random yang dikombinasikan dengan metode late acceptance.

Penelitian terdahalu tersebut telah berhasil menerapkan strategi high level heuristic untuk menyelesaikan beberapa permasalahan optimasi dengan mekanisme seleksi LLH menggunakan metode simple random. Namun, metode simple random kurang efektif karena pencarian LLH dilakukan secara acak. Seleksi LLH tidak merata. LLH yang terpilih secara acak belum tentu optimal, bisa jadi LLH yang tidak terpilih adalah LLH yang optimal. Oleh karena itu, perlu adanya peningkatan kinerja dari high level heuristic dalam menemukan solusi yang optimal pada berbagai permasalahan optimasi.

Penelitian ini mengusulkan strategi high level heuristic yang baru dalam seleksi LLH dan move acceptance agar dapat meningkatkan kinerja pencarian setiap permasalahan optimasi. Dalam penelitian ini, seleksi LLH dilakukan dengan mengadaptasi pendekatan variable neighborhood search (VNS). VNS merupakan teknik pencarian solusi yang mengubah lingkungan secara sistematis dalam pencarian untuk menghasilkan global optimal [9]. VNS melibatkan pencarian lokal secara berurutan untuk mengubah solusi saat sehingga menjadi optimal secara lokal. Prosedur ini efektif untuk meningkatkan intensifikasi yang memakan waktu [10]. VNS efisien dalam meningkatkan hasil pencarian [11].

Selain seleksi LLH, komponen penting lainnya yang menentukan keberhasilan hyper-heuristics adalah mekanisme move acceptance. Dalam penelitian ini, VNS dikombinasikan dengan mekanisme move acceptance Hill Climbing. Hasil yang diharapkan dari penelitian ini adalah strategi high level heuristic yang dapat meningkatkan kinerja hyper-heuristics dalam menemukan solusi yang lebih optimal pada masalah optimasi lintas domain.

Strategi high level heuristic sebagai seleksi hyperheuristics yang diusulkan, diuji coba menggunakan framework Hyper-Heuristics Flexible (HyFlex) ${ }^{1}$. HyFlex merupakan sebuah framework yang menyediakan antarmuka yang mudah digunakan untuk pengembangan dan metolodogi pencarian seleksi hyper-heuristics dengan implementasi beberapa domain masalah optimasi berbeda yang telah memiliki representasi solusi dan low level heuristic [12]. Problem domain pada HyFlex ini merupakan benchmark dari permasalahan optimasi kombinatorik, di mana kinerja teknik adaptasi lintas domain yang berbeda dapat dinilai dan dibandingkan. Terdapat enam problem domain masalah optimasi kombinatorial pada framework HyFlex, yaitu satisfiability (SAT), one dimensional bin packing, permutation flow shop, personnel scheduling, TSP, dan VRP [13]. Hasil implementasi strategi high level heuristic pada HyFlex akan dibandingkan dengan strategi

${ }^{1}$ http://intip.in/hyperheuristics 
high level heuristic pada penelitian sebelumnya yang diimplementasikan ulang.

\section{Kajian Pustaka}

Penelitian hyper-heuristics terdahulu dilakukan dengan mengkombinasikan metode untuk mekanisme seleksi LLH dan move acceptance. Penelitian [8] telah mengusulkan strategi high level heuristic dengan menguji efek kinerja mekanisme pemilihan stokastik sederhana, i.e. simple random, terhadap pemilihan rangkaian LLH di dalam kerangka hyper-heuristics dengan memperkenalkan kelas baru metode pemilihan heuristik berdasarkan pilihan roulette-wheel dan menggabungkannya dengan metode Late Acceptance. Simple Random digunakan untuk menerapkan LLH secara acak dari LLH yang tersedia. Penelitian tersebut diuji coba terhadap enam problem dom ain pada HyFlex. Penelitian hyper-heuristics tentang mencari nilai parameter tuning telah dibahas dalam penelitian [14].

Penelitian [15] mengusulkan strategi high level heuristic yang dikenal sebagai gene expression programming hyperheuristics (GEP-HH). Pada model GEP-HH, mekanisme seleksi LLH menggunakan pendekatan dynamic multi-armed bandit-extreme value based reward dan metode move acceptance menggunakan gene expression programming (GEP). Model tersebut telah menerapkan seleksi hyper-heuristics untuk menyelesaikan permasalahan kombinatorik lintas domain, yaitu: exam timetabling dan dynamic vehicle routing problem (DVRP). Pada exam timetabling, waktu eksekusi ditentukan dengan menggunakan patokan software untuk memastikan keadilan (fair) perbandingan antara penelitian yang dilakukan dan platform lainnya. Waktu eksekusi yang ditentukan adalah 10 menit. Pada dynamic vehicle routing, waktu eksekusi disesuaikan seperti penelitian sebelumnya, yaitu 750 detik. Hasil penerapan model GEP-HH dibandingkan dengan metode state-of-the-art untuk DVRP. Hasil komputasional menunjukkan bahwa secara umum, model GEP-HH lebih unggul dari metode yang telah ada sebelumnya. Pada penelitiam [11], VNS digunakan dalam framework metaheuristics dan hanya digunakan dalam satu problem domain saja, yaitu VRP.

Metode hyper-heuristics juga sudah banyak digunakan untuk menyelesaikan permasalahan optimasi kombinatorik lainya seperti pada [16] [17] yang digunakan untuk menyelesaikan permasalahan multi-objective examination timetabling problem. Sedangkan pada [1819], hyper-heuristics digunakan untuk optimasi rencana perjalanan dengan menggunakan moda transportasi umum. Keterbaruan dari penelitian adalah bahwa ini adalah studi pertama yang menginvestigasi metode VNS sebagai strategi dalam hyper-heuristics, yang tidak hanya untuk menyelesaikan satu permasalahan yang spesifik, tetapi enam permasalahan lintas domain sekaligus.

\section{Metode}

\section{a. Identifikasi Masalah}

Penelitian ini mengembangkan metode hyperheuristics sebagai strategi high level heuristic dalam memilih LLH dari rangkaian LLH yang telah ada pada masingmasing domain masalah optimasi. Hyper-heuristics adalah sebuah metode, algoritma, atau mekanisme pembelajaran untuk mencari atau menghasilkan heuristik sehingga dapat menyelesaikan masalah pencarian komputasional [5]. Tujuan dari penelitian ini adalah meningkatkan kinerja dari hyper-heuristics dalam mengoptimalkan masalah optimasi lintas domain.

\section{b. Datasets}

Data yang digunakan adalah data yang terdapat pada HyFlex. HyFlex dapat dilihat sebagai package framework dan benchmark datasets untuk optimasi kombinatorik, di mana kinerja teknik adaptasi lintas domain yang berbeda dapat dinilai dan dibandingkan dengan baik. Terdapat enam domain permasalahan kombinatorial yang secara penuh diimplementasikan pada HyFlex, yaitu satisfiability, one dimensional bin packing, permutation flow shop, personnel scheduling, traveling salesman problem (TSP), dan vehicle routing problem (VRP). Satisfiability merupakan permasalahan pemenuhan aljabar boolean. Masalah bin packing adalah masalah mengoptimalkan penggunaan sebuah bin dalam pengemasan barang. Masalah flow shop adalah masalah untuk mengoptimalkan urutan kerja mesin sehingga pekerjaan cepat selesai. Masalah personnel schedulling adalah masalah mengoptimalkan jam kerja karyawan sehingga tidak ada karyawan yang memiliki jam kerja lebih banyak. Permasalahan TSP adalah masalah mengoptimalkan jarak yang ditempuh oleh seseorang dalam mengunjungi beberapa tempat. Masalah VRP adalah masalah mengoptimalkan rute kendaraan yang harus dikunjungi oleh kendaraan. Setiap permasalahan optimasi menggunakan data yang nyata (instance) dari HyFlex. Untuk menggunakan data pada HyFlex, dapat memanggil fungsi-fungsi (methods) yang terdapat pada HyFlex.

\section{c. Desain Algoritma}

Desain hyper-heuristics ini merupakan pengembangan hyper-heuristics sebagai strategi high level heuristic yang diusulkan. Pada tahap ini, high level heuristic akan menyeleksi salah satu low level heuristic dari rangkaian low level heuristic yang ada. Pada setiap iterasi, low level heuristic yang terpilih akan menghasilkan sebuah solusi baru, kemudian solusi yang dihasilkan tersebut akan dipertimbangkan untuk diterima atau tidak untuk menggantikan solusi sebelumnya berdasarkan kriteria move acceptance. Jadi, ada dua strategi atau metode yang menentukan kinerja dari hyper-heuristics, yaitu: metode memilih LLH, dan metode move acceptance. 


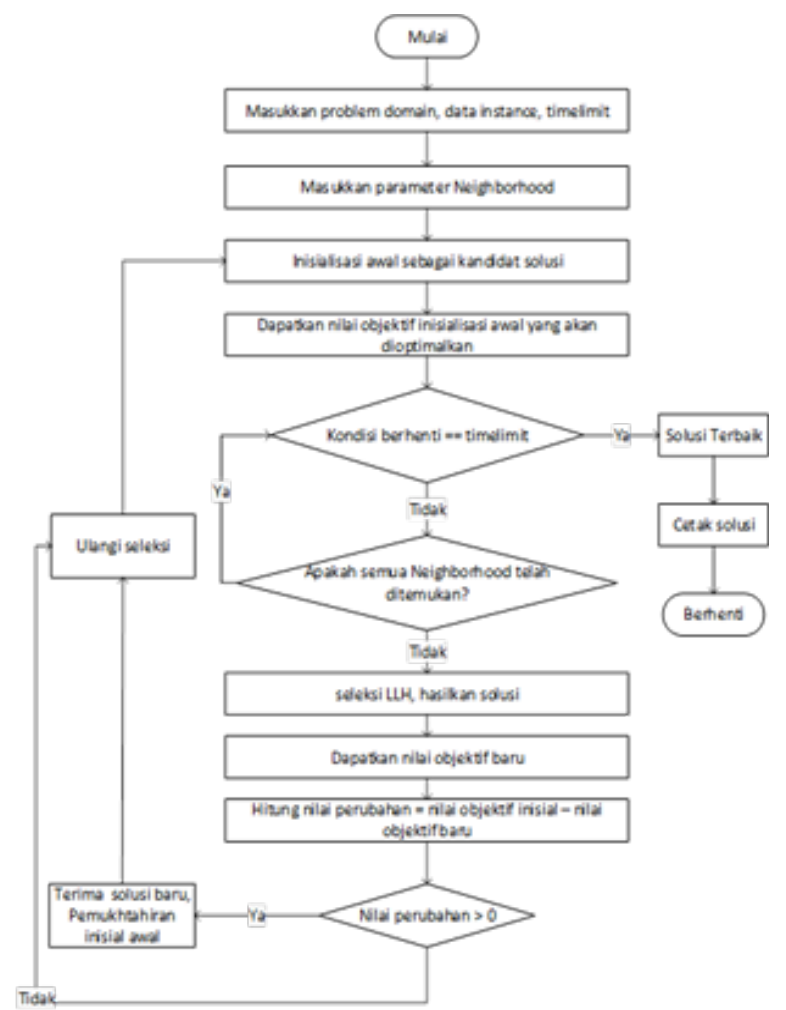

Gambar 1. High Level Strategi yang Diusulkan

Tabel 1. Rangkaian Low Level Heuristic setiap Domain

\begin{tabular}{clccccc}
\hline No & Permasalahan optimasi & Mutation & Ruin-Recreate & Crossover & Local Search & Total \\
\hline 1 & Satisfiability & 6 & 1 & 2 & 2 & 11 \\
2 & One Dimensional Bin Packing & 3 & 2 & 1 & 2 & 8 \\
3 & Permutation Flow Shop & 5 & 2 & 3 & 3 & 15 \\
4 & Personnel scheduling & 1 & 3 & 3 & 4 & 12 \\
5 & Traveling salesman Problem & 5 & 1 & 2 & 2 & 13 \\
6 & Vehicle Routing Problem & 3 & 2 & 3 & 10 \\
\hline
\end{tabular}

Dalam penelitian ini, metode seleksi LLH Variable Neighborhood Search (VNS) dikombinasikan dengan metode move acceptance Hill Climbing yang selanjutnya disebut VNS-HC. Di dalam strategi ini, setiap pencarian LLH dilakukan secara sistematis berdasarkan urutan neighborhood, dan setiap LLH yang terpilih akan membangkitkan satu solusi karena pencarian berbasis single-point-search. Untuk move acceptance, metode ini hanya menerima solusi yang mengalami peningkatan. Pada desain high level heuristic VNS-HC ini dimulai dengan inisialisasi solusi untuk mendapatkan solusi awal. Dari solusi awal ini didapatkan nilai fungsi tujuan yang akan menjadi pembanding awal dengan solusi baru yang akan dihasilkan pada iterasi berikutnya. Untuk melihat detail proses dari strategi high level ini dapat dilihat pada Gambar 1.

Low Level Heuristic (LLH) yang digunakan di dalam penelitian ini adalah heuristik yang terdapat pada setiap permasalahan optimasi di dalam framework HyFlex [13]. Rangkaian LLH dalam HyFlex dikelompokkan menjadi empat kelompok, yaitu mutasi, ruin-recreate, local search, dan crossover.

Kelompok heuristik mutasi melakukan perubahan secara acak pada solusi dengan cara menukar, mengubah, membuang, menambah, atau menghapus komponen solusi. Pada kelompok ruin-recreate perubahan pada solusi dilakukan dengan cara merombak sebagian solusi dan membangun atau membuatnya kembali. Kelompok heuristik local search secara iteratif membuat perubahan kecil pada solusi, dan hanya menerima solusi yang meningkat sampai kondisi local optimum ditemukan atau kondisi berhenti terpenuhi. Heuristik ini berbeda dari kelompok heuristik mutasi karena heuristik menggabungkan proses perbaikan berulang dan mereka menjamin bahwa solusi yang baik akan dihasilkan. Pada kelompok heuristik crossover solusi baru dihasilkan dengan cara melakukan perubahan dengan mengambil dua solusi, menggabungkannya dan mengembalikan solusi baru. Tabel 1 merupakan jumlah rangkaian low level heuristic yang terdapat pada HyFlex. 


\section{d. Implementasi}

Pada tahap ini, strategi high level heuristic yang diusulkan dan strategi high level heuristic pada penelitian sebelumnya diimplementasikan. Implementasi dalam penelitian ini dilakukan pada komputer dengan prosesor Intel Pentium N3710 1.6 GHz dan memori 4096MB. Hasil desain algoritma diimplementasikan pada framework HyFLex [13] menggunakan tools NetBeans IDE 8.2. Implementasi pada HyFlex dilakukan dengan cara memanggil fungsi-fungsi (methods) dan libraries yang ada pada HyFlex.

\section{e. Uji Coba}

Tahap uji coba ini merupakan tahap untuk melihat kinerja strategi high level heuristic yang diusulkan dengan strategi high level heuristic pada penelitian sebelumnya. Uji coba dilakukan dengan cara menjalankan algoritma sebanyak 31 kali eksekusi pada setiap instance dari CheSC dengan running time (elapsed time) yang sama. Batasan running time dan jumlah 31 kali ini berdasarkan literatur sebelumnya pada [7] dan [8]. Uji coba ini menghasilkan nilai fungsi fitness (untuk dicari solusi paling minimal) dari masing-masing problem instance. Pada pengujian ini terdapat lima instance pada setiap enam problem domain, sehingga terdapat 30 variasi instance data. Setiap strategi high level heuristic diujicoba dengan data yang sama. Dari hasil eksekusi, didapatkan penyebaran data nilai fungsi fitness setiap instance. Dari data hasil eksekusi tersebut dihitung nilai terbaik (minimal), kuartil pertama, median, kuartil ketiga, nilai maksimal, dan rata-rata yang akan dijadikan nilai perbandingan untuk setiap metode. Untuk melihat hasil uji coba nilai fungsi fitness terhadap masingmasing strategi dapat dilihat pada Tabel 2 dan Tabel 3.

\section{Hasil dan Diskusi}

Untuk menguji kinerja VNS-HC, dilakukan perbandingan dengan strategi high level heuristic Simple Random-Hill Climbing (Rand-HC) dalam penelitian sebelumnya yang diimplementasikan ulang. Kinerja diuji berdasarkan analisis data dari nilai minimal, kuartil pertama, median, kuartil ketiga, dan nilai maksimal fungsi fitness yang dihasilkan pada saat eksekusi. Pengujian kinerja pada masing-masing strategi dilakukan dengan tiga perbandingan. Pertama, membandingkan penyebaran data secara keseluruhan dari hasil eksekusi masing-masing strategi menggunakan diagram boxplot. Kedua, secara spesifik membandingkan nilai median untuk mengukur pemusatan data yang menjadi nilai tengah dari sekelompok data. Ketiga, membandingkan nilai minimal fungsi fitness hasil eksekusi masing-masing strategi. Karena fungsi tujuan dari setiap permasalahan optimasi adalah meminimalkan, maka kinerja dari strategi high level heuristic yang diusulkan dalam menghasilkan nilai minimal fungsi objektif perlu diuji. Secara umum, hasil penelitian secara komputasi dengan algoritma hyperheuristic Random - Hill Climbing (Rand-HC) dapat dilihat pada Tabel 2, sedangkan hasil dari algoritma hyper-huristic Variable Neighbourhood Search - Hill Climbing (VNS-HC) dapat dilihat pada Tabel 3.

Tabel 2. Hasil Eksekusi Rand-HC

\begin{tabular}{|c|c|c|c|c|c|c|c|}
\hline Permasalahan & Instance & Min & Q1 & Median & Q3 & Maksimal & Rata-Rata \\
\hline \multirow{5}{*}{ SAT } & 0 & 70 & 77 & 93 & 95 & 95 & 86,45161 \\
\hline & 1 & 73 & 73 & 75 & 77 & 77 & 75,19355 \\
\hline & 2 & 78 & 78 & 78 & 79 & 79 & 78,35484 \\
\hline & 3 & 38 & 38 & 38 & 39 & 41 & 38,70968 \\
\hline & 4 & 58 & 58 & 63 & 64 & 79 & 62,22581 \\
\hline \multirow{5}{*}{ Bin Packing } & 0 & 0,101623 & 0,101623 & 0,101623 & 0,101623 & 0,101623 & 0,101623 \\
\hline & 1 & 0,099989 & 0,099989 & 0,099989 & 0,099989 & 0,099989 & 0,099989 \\
\hline & 2 & 0,107186 & 0,107186 & 0,107186 & 0,107186 & 0,107186 & 0,107186 \\
\hline & 3 & 0,084335 & 0,084341 & 0,084341 & 0,084341 & 0,084341 & 0,084341 \\
\hline & 4 & 0,04753 & 0,04753 & 0,04753 & 0,04753 & 0,04753 & 0,04753 \\
\hline \multirow{5}{*}{ Flow Shop } & 0 & 6424 & 6424 & 6497 & 6497 & 6534 & 6473,806 \\
\hline & 1 & 6415 & 6415 & 6464 & 6464 & 6464 & 6448,194 \\
\hline & 2 & 6507 & 6507 & 6507 & 6507 & 6507 & 6507 \\
\hline & 3 & 6491 & 6491 & 6491 & 6491 & 6491 & 6491 \\
\hline & 4 & 6517 & 6517 & 6517 & 6539,5 & 6540 & 6523,645 \\
\hline \multirow{5}{*}{$\begin{array}{l}\text { Personnel } \\
\text { Scheduling }\end{array}$} & 0 & 3406 & 3422,5 & 3446 & 3464,5 & 3512 & 3446,323 \\
\hline & 1 & 2538 & 2870 & 3545 & 3907,5 & 5402 & 3498,903 \\
\hline & 2 & 445 & 715 & 1870 & 2027,5 & 3475 & 1606,484 \\
\hline & 3 & 33 & 43 & 46 & 49,5 & 337 & 68 \\
\hline & 4 & 38 & 43 & 45 & 52 & 148 & 50,58065 \\
\hline
\end{tabular}




\begin{tabular}{lccccccc}
\hline Permasalahan & Instance & Min & Q1 & Median & Q3 & Maksimal & Rata-Rata \\
\hline \multirow{4}{*}{ TSP } & 0 & 51426,79 & 51426,79 & 51426,79 & 51426,79 & 51426,79 & 51426,79 \\
& 1 & 118075,8 & 118075,8 & 118075,8 & 118075,8 & 118075,8 & 118075,8 \\
& 2 & 7066,498 & 7066,498 & 7066,498 & 7066,498 & 7066,498 & 7066,498 \\
& 3 & 44428,89 & 44428,89 & 44428,89 & 44428,89 & 44428,89 & 44428,89 \\
& 4 & 9415,178 & 9415,178 & 9418,576 & 9418,576 & 9418,576 & 9417,151 \\
& 0 & 6195,994 & 6195,994 & 6195,994 & 6195,994 & 6195,994 & 6195,994 \\
\multirow{2}{*}{ VRP } & 1 & 21695,58 & 21695,58 & 21695,58 & 21695,58 & 21695,79 & 21695,59 \\
& 2 & 14439,79 & 14439,79 & 14439,79 & 14439,79 & 14439,79 & 14439,79 \\
& 3 & 8301,908 & 8301,908 & 8301,908 & 8301,908 & 8301,908 & 8301,908 \\
& 4 & 15388,98 & 15388,98 & 15388,98 & 15388,98 & 15388,98 & 15388,98 \\
\hline
\end{tabular}

Tabel 3. Hasil Eksekusi VNS-HC

\begin{tabular}{|c|c|c|c|c|c|c|c|}
\hline Permasalahan & Ins & Min & Q1 & Median & Q3 & Maks & Rata-Rata \\
\hline \multirow{5}{*}{ SAT } & 0 & 76 & 76 & 79 & 79 & 88 & 78,6129 \\
\hline & 1 & 70 & 70 & 70 & 70 & 72 & 70,12903 \\
\hline & 2 & 68 & 68,5 & 73 & 81 & 82 & 74,48387 \\
\hline & 3 & 26 & 26 & 26 & 26 & 26 & 26 \\
\hline & 4 & 50 & 50,5 & 52 & 53 & 53 & 51,83871 \\
\hline \multirow{5}{*}{ Bin Packing } & 0 & 0,016965 & 0,016967 & 0,01697 & 0,020719 & 0,022096 & 0,018396 \\
\hline & 1 & 0,016642 & 0,016648 & 0,016657 & 0,016658 & 0,021036 & 0,016799 \\
\hline & 2 & 0,028275 & 0,028425 & 0,028425 & 0,030387 & 0,284251 & 0,040913 \\
\hline & 3 & 0,026618 & 0,026618 & 0,026618 & 0,026629 & 0,027599 & 0,026809 \\
\hline & 4 & 0,006139 & 0,006139 & 0,006982 & 0,007226 & 0,012342 & 0,007473 \\
\hline \multirow{5}{*}{ Flow Shop } & 0 & 6469 & 6469 & 6469 & 6469 & 6469 & 6469 \\
\hline & 1 & 6372 & 6372 & 6420 & 6420 & 6420 & 6398,323 \\
\hline & 2 & 6473 & 6473 & 6473 & 6473 & 6473 & 6473 \\
\hline & 3 & 6386 & 6386 & 6386 & 6390 & 6390 & 6387,29 \\
\hline & 4 & 6506 & 6506 & 6506 & 6552 & 6552 & 6525,29 \\
\hline \multirow{5}{*}{$\begin{array}{l}\text { Personnel } \\
\text { Scheduling }\end{array}$} & 0 & 3442 & 3477 & 3497 & 3500 & 3502 & 3487,806 \\
\hline & 1 & 3165 & 3290 & 3290 & 3290 & 3290 & 3272,581 \\
\hline & 2 & 490 & 535 & 610 & 872,5 & 2080 & 917,0968 \\
\hline & 3 & 25 & 37 & 46 & 50 & 68 & 44,41935 \\
\hline & 4 & 37 & 46 & 54 & 61 & 260 & 75,41935 \\
\hline \multirow{5}{*}{ TSP } & 0 & 51653,44 & 51653,44 & 51653,44 & 51653,44 & 51653,44 & 51653,44 \\
\hline & 1 & 117399,1 & 117399,1 & 117399,1 & 117399,1 & 117420,8 & 117403,3 \\
\hline & 2 & 7132,697 & 7132,697 & 7132,697 & 7132,697 & 7132,697 & 7132,697 \\
\hline & 3 & 44444,5 & 44444,5 & 44444,5 & 44444,5 & 44444,5 & 44444,5 \\
\hline & 4 & 9349,059 & 9349,059 & 9349,059 & 9349,059 & 9349,059 & 9349,059 \\
\hline \multirow{5}{*}{ VRP } & 0 & 6205,338 & 6205,338 & 6205,338 & 6205,338 & 6205,338 & 6205,338 \\
\hline & 1 & 22703,79 & 22703,79 & 22703,79 & 22703,79 & 22703,79 & 22703,79 \\
\hline & 2 & 14412,67 & 14412,67 & 14412,67 & 14412,67 & 14412,67 & 14412,67 \\
\hline & 3 & 6307,648 & 6307,648 & 6307,648 & 6307,648 & 6307,648 & 6307,648 \\
\hline & 4 & 14326,73 & 14326,73 & 14326,73 & 14326,73 & 14326,73 & 14326,73 \\
\hline
\end{tabular}




\section{a. Perbandingan Penyebaran Data}

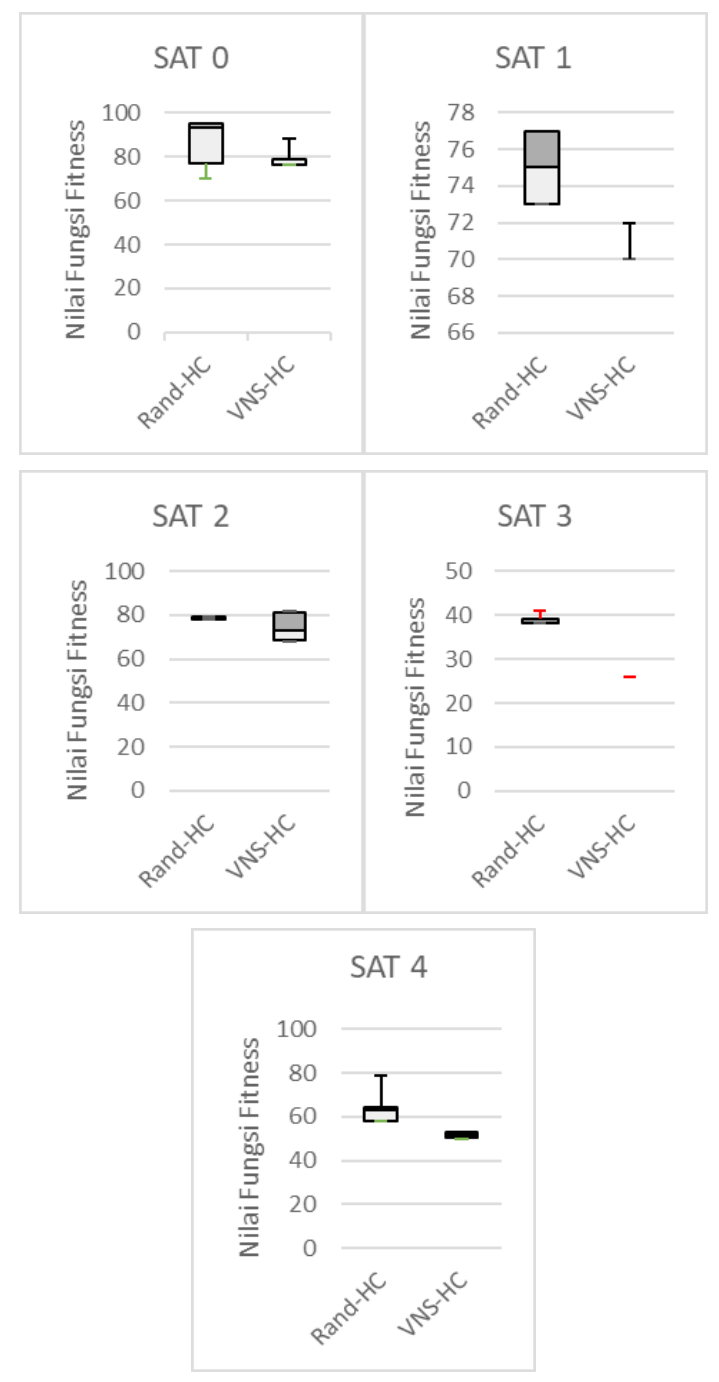

Gambar 2. BoxPlot Kinerja Rand-HC dan VNS-HC pada Domain SAT

Perbandingan penyebaran data dari strategi high level berdasarkan nilai minimal, kuartil pertama, median, kuartil ketiga, dan nilai maksimal menggunakan diagram boxplot. Perbandingan penyebaran nilai fungsi fitness dari algoritma Rand-HC versus VNS-HC yang diuji coba pada keenam problem domain yang berbeda secara berurutan dapat dilihat pada Gambar 2 - Gambar 7. Perlu diperhatikan bahwa nilai fungsi fitness disini semakin kecil semakin bagus. Dari Gambar 2 - Gambar 7, dapat dilihat bahwa VNS-HC mengungguli Rand-HC hampir pada semua problem domain.

Selanjutnya, untuk membandingkan kedua algoritma lebih sistematis, untuk algoritma dengan nilai fungsi fitness lebih kecil akan diberikan satu poin. Jika nilai fitness yang dihasilkan sama, maka setiap algoritma diberikan satu poin. Poin yang dihasilkan akan dijumlahkan untuk mengetahui kinerja dari masing-masing algoritma. Karena ada 5 problem domain dan masing-masing domain ada 5 instances, maka jumlah maksimal skor untuk setiap problem domain optimasi adalah 25 poin, dan jumlah maksimal semua instance pada problem domain adalah 150 poin. Jumlah poin yang lebih besar menyatakan strategi tersebut memiliki kinerja yang lebih baik.

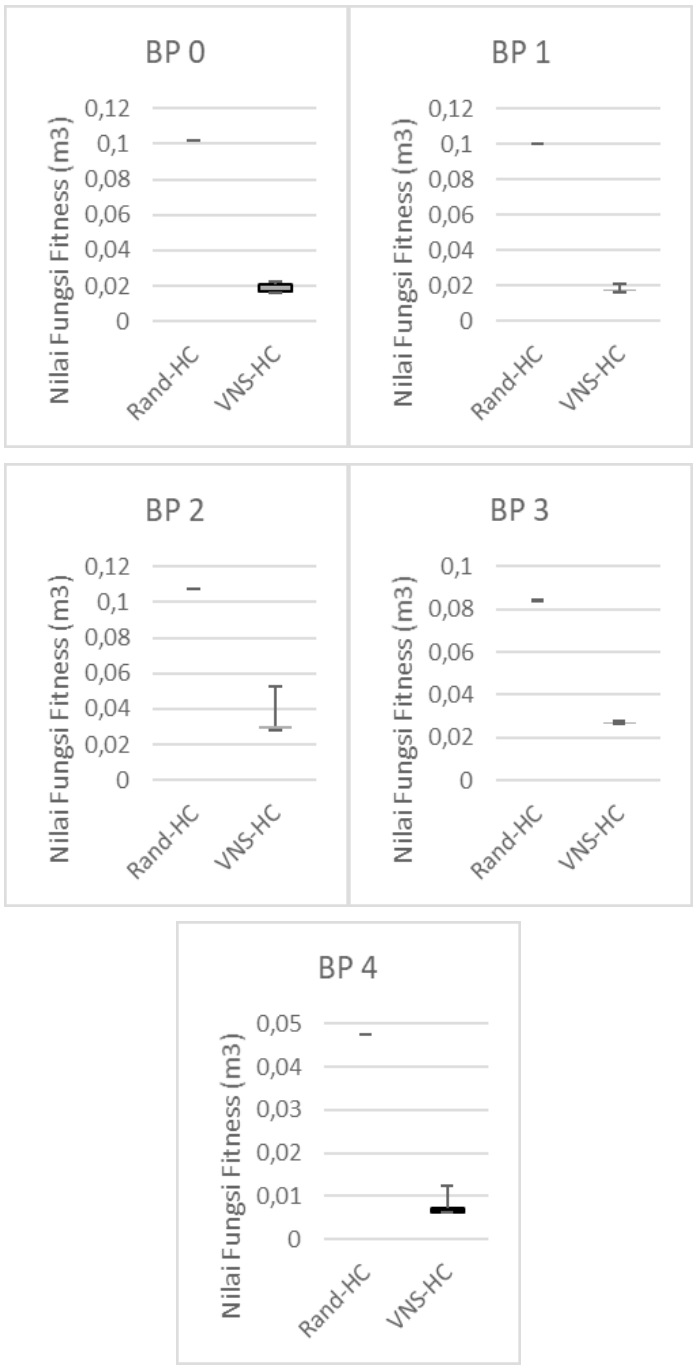

Gambar 3. BoxPlot Kinerja Rand-HC dan VNS-HC pada Domain BP

Secara ringkas, perbandingan Rand-HC dan VNS$\mathrm{HC}$ terhadap masing-masing instance pada setiap problem domain optimasi, adalah sebagai berikut:

Pada permasalahan optimasi satisfiability (SAT), VNS-HC memiliki kinerja lebih baik daripada Rand-HC, terutama pada instance ke-1, ke-3, dan ke-4 seperti yang dapat dilihat pada diagram boxplot pada Gambar 2. Pada permasalahan SAT, VNS-HC unggul dengan total skor 22 poin sedangkan Rand-HC dengan total skor 3 poin.

Pada permasalahan optimasi bin packing, VNS-HC memiliki kinerja lebih baik pada semua instance dataset seperti yang terlihat pada boxplot seperti Gambar 3 dengan perbedaan yang sangat jauh Rand-HC. Pada permasalahan bin packing, VNS-HC unggul dengan total skor 25 poin sedangkan Rand-HC dengan total skor 0 poin.

Pada permasalahan optimasi flow shop, VNS-HC memiliki kinerja lebih baik daripada Rand-HC pada 
indeks instance dataset ke-1, ke-2, dan ke-3 seperti yang terlihat pada boxplot seperti Gambar 4. Pada permasalahan flow shop, VNS-HC unggul dengan total skor 21 poin sedangkan Rand-HC dengan total skor 4 poin.

Pada permasalahan optimasi personnel scheduling, VNS-HC memiliki kinerja lebih baik daripada RandHC pada beberapa nilai pada setiap instance, seperti nilai median pada instance ke-1 dan instance ke-2 seperti yang terlihat pada boxplot seperti Gambar 5. Pada permasalahan personnel scheduling, VNS-HC mendapatkan skor imbang dengan Rand-HC dengan total skor 13 poin.

Pada permasalahan optimasi TSP, VNS-HC memiliki kinerja lebih baik daripada Rand-HC pada indeks instance dataset ke-1 dan ke-4 seperti yang terlihat pada boxplot Gambar 6. Pada permasalahan ini, VNS-HC kalah dengan total skor 10 poin dibandingkan Rand-HC dengan total skor 15 poin.

Pada permasalahan optimasi VRP, metode hyperheuristics VNS-HC memiliki kinerja lebih baik daripada Rand-HC pada indeks instance dataset ke-2, ke-3, dan ke-4 seperti yang terlihat pada boxplot Gambar 7. Pada permasalahan ini, VNS-HC unggul dengan total skor 15 poin sedangkan Rand-HC dengan total skor 10 poin.
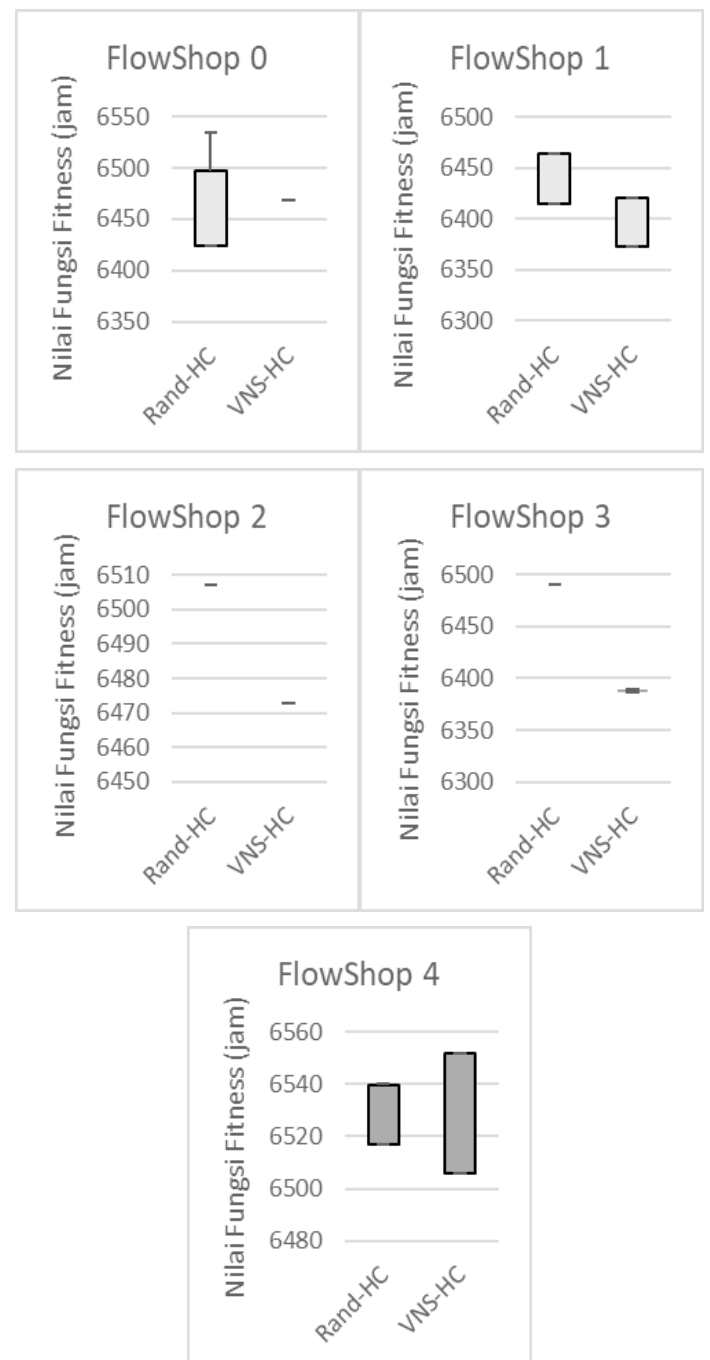

Gambar 4. BoxPlot Kinerja Rand-HC dan VNS-HC pada Domain FlowShop
Secara keseluruhan, pada diagram boxplot terhadap nilai minimal, kuartil pertama, median, kuartil ketiga, dan nilai maksimal hasil eksekusi, strategi VNS-HC memiliki kinerja yang lebih baik daripada Rand-HC dengan total skor 106, sedangkan Rand-HC dengan skor 45.

\section{b. Perbandingan Nilai Median}

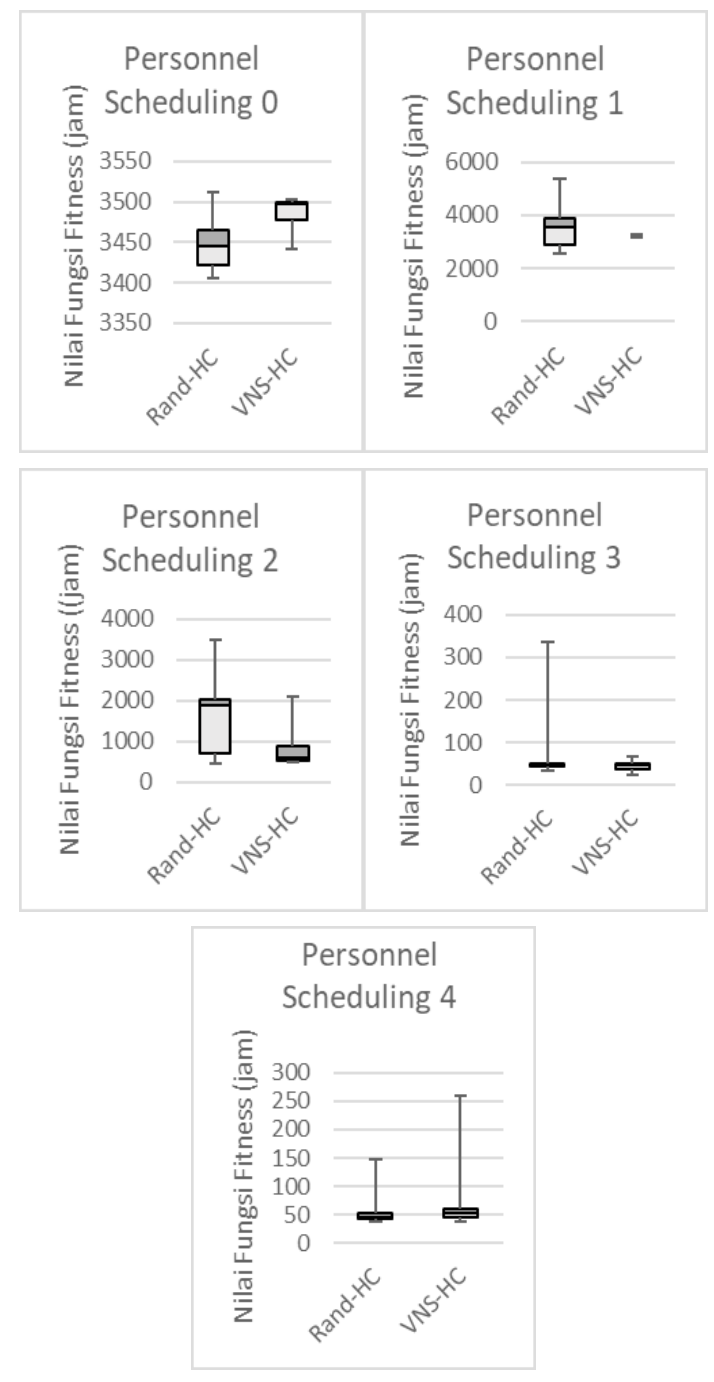

Gambar 5. BoxPlot Kinerja Rand-HC dan VNS-HC pada Domain PS

Perbandingan nilai median untuk mengukur pemusatan data yang menjadi nilai tengah dari sekelompok data. Untuk melihat persaingan dari kedua metode tersebut, digunakan sistem poin FIFA. Hasil dari kinerja setiap strategi pada setiap permasalahan optimasi akan diberikan tiga (3) poin untuk strategi yang menang, satu (1) poin untuk hasil imbang, dan tidak ada (0) poin untuk strategi yang kalah. Menang, kalah, atau imbang tersebut dihitung dari penjumlahan peningkatan dan penurunan nilai pada kedua metode. Jika total dari peningkatan bernilai positif, maka metode VNS-HC dianggap menang dan diberikan tiga poin. Persaingan ini bertujuan untuk mencari strategi high level heuristic yang paling optimal untuk menyelesaikan masalah lintas domain. Berdasarkan 
hasil perhitungan jumlah poin pada seluruh instance (30 instance), nilai median pada metode VNS-HC unggul pada lima permasalahan optimasi, yaitu pada permasalahan optimasi SAT, bin packing, flow shop, personnel scheduling, dan VRP. Sedangkan pada permasalahan optimasi TSP, metode VNS-HC mendapat poin seri dengan metode Rand-HC. Hal ini menyatakan bahwa strategi high level dengan metode seleksi low level secara sistematis, dapat meningkatkan kinerja hyper-heuristics dalam menyelesaikan masalah optimasi lintas domain. Untuk melihat grafik peningkatan dan penurunan kinerja pada setiap permasalahan optimasi, dapat dilihat pada Gambar 8.
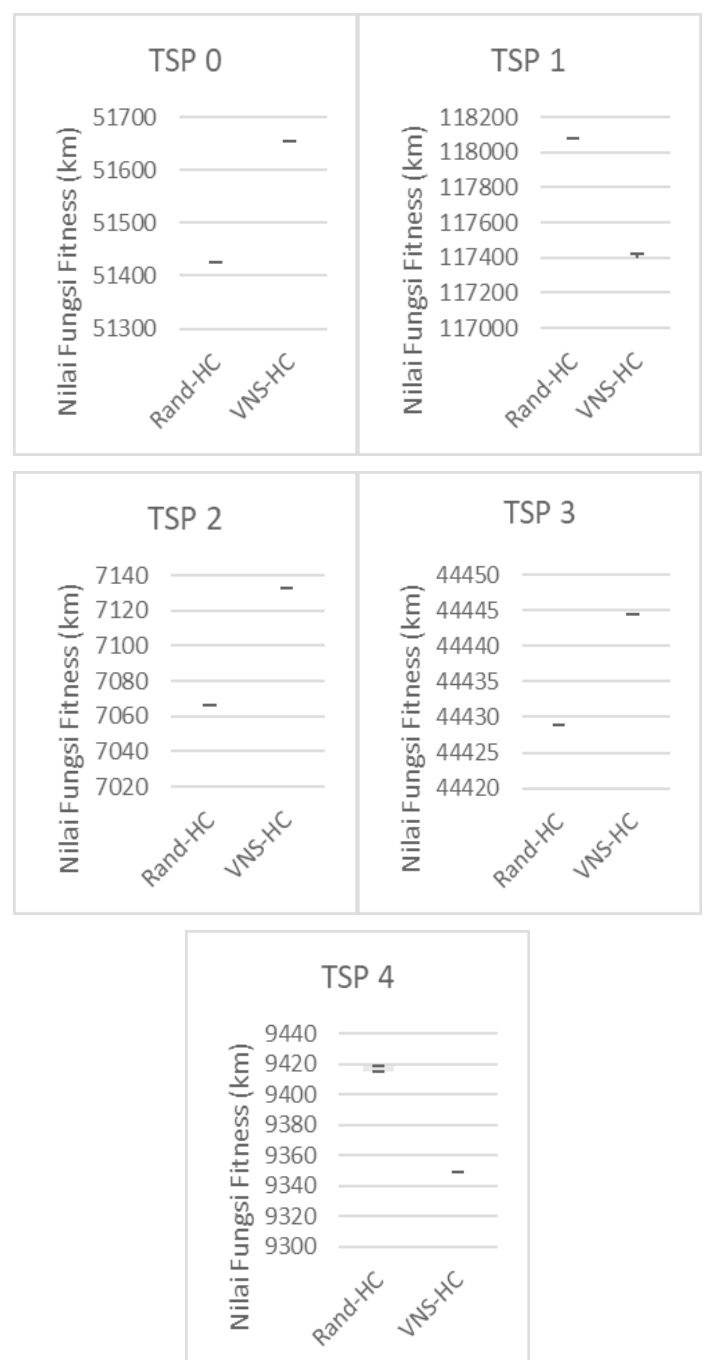

Gambar 6. BoxPlot Kinerja Rand-HC dan VNS-HC pada Domain TSP

\section{c. Perbandingan Nilai Minimal}

Perbandingan nilai minimal untuk menguji kinerja strategi high level heuristik dalam menghasilkan solusi optimal (fungsi fitness minimal). Untuk menguji kinerja setiap strategi dalam menemukan nilai fungsi fitness minimal, maka dilakukan perbandingan nilai minimal terhadap kedua metode dengan sistem poin yang sama dengan pengukuran nilai median.

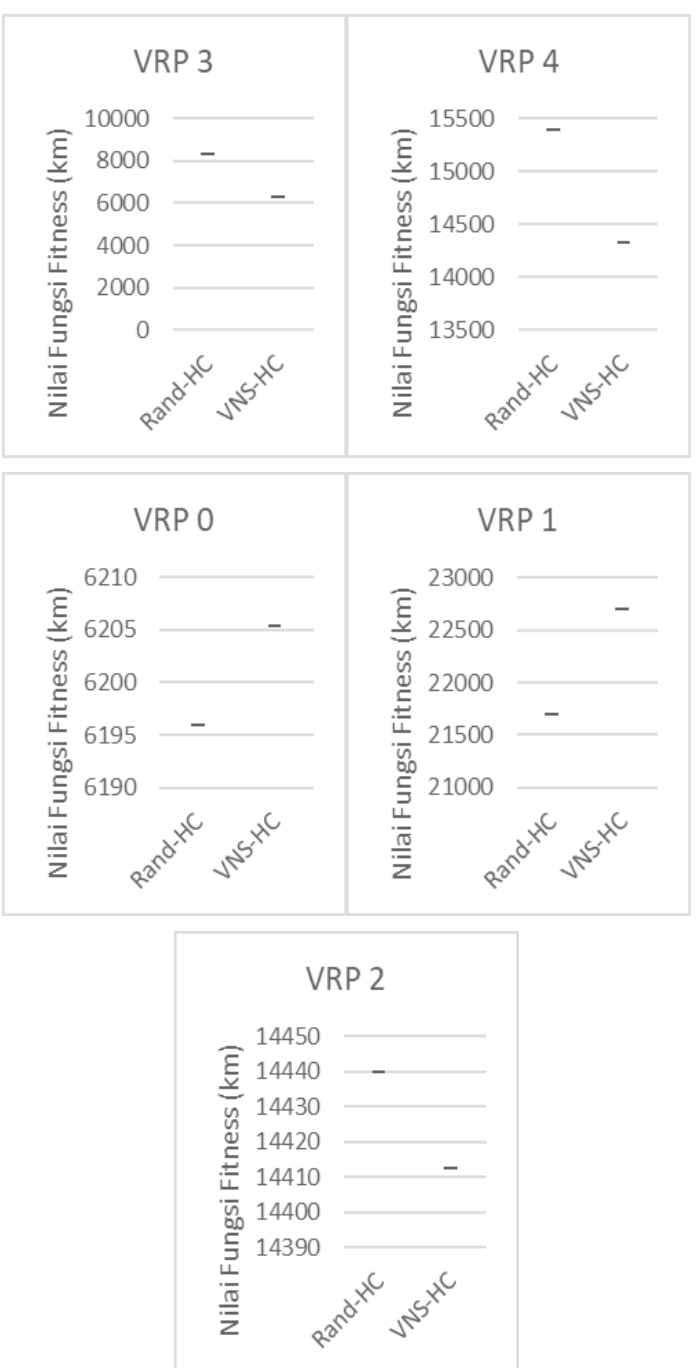

Gambar 7. BoxPlot Kinerja Rand-HC dan VNS-HC pada Domain VRP

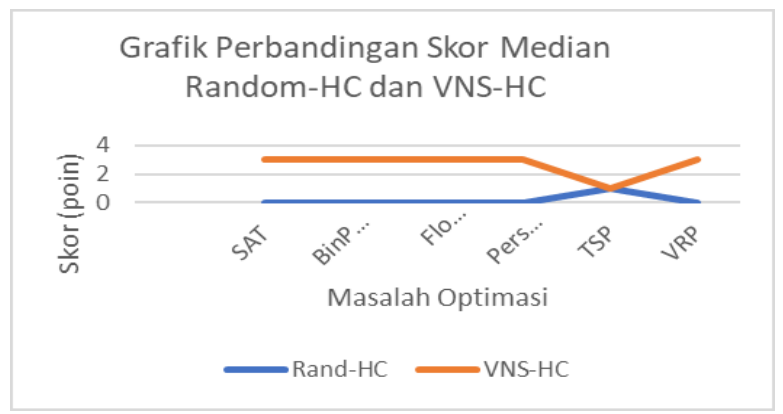

Gambar 8. Grafik Perbandingan Skor Nilai Median

Berdasarkan hasil perhitungan jumlah poin pada seluruh instance (30 instance), nilai minimal pada metode VNS-HC secara keseluruhan unggul daripada strategi Rand-HC. VNS-HC unggul pada lima permasalahan optimasi, yaitu pada permasalahan optimasi SAT, bin packing, flow shop, Personnel Scheduling, dan VRP, sedangkan pada permasalahan optimasi TSP, strategi VNS-HC mendapat poin seri dengan metode Rand-HC. Hal ini menyatakan bahwa strategi high level dengen metode seleksi low level heuristics secara sistematis, dapat memberikan hasil yang lebih optimal dalam menyelesaikan 
masalah optimasi lintas domain. Untuk melihat grafik peningkatan dan penurunan nilai minimal pada setiap permasalahan optimasi, dapat dilihat pada Gambar 9.

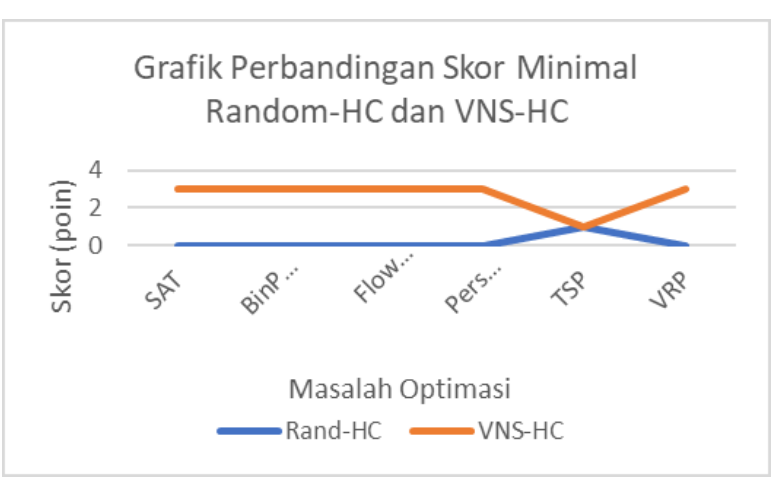

Gambar 9. Grafik Perbandingan Skor Nilai Minimal

\section{Kesimpulan}

Berdasarkan hasil eksperimen yang telah dilakukan dalam penelitian ini, pengujian terhadap seleksi LLH secara sistematis dengan mengadaptasi metode Variable Neighborhood Search yang dikombinasikan dengan metode move acceptance Hill Climbing sebagai strategi high level heuristic dapat meningkatkan kinerja dari hyper-heuristics yang diuji coba pada lintas enam problem domain optimasi dari HyFlex. Berdasarkan metode perbandingan yang berbeda dari enam permasalahan optimasi, terdapat empat permasalahan optimasi yang selalu mengalami peningkatan, yaitu SAT, flow shop, bin packing, dan VRP sedangkan pada domain lainnya mengalami penurunan dan tidak ada peningkatan. Secara ringkas dapat dikatakan bahwa algoritma baru yang diusulkan pada penelitian ini terbukti memiliki performa algoritma sebelumnya dari literatur.

Kenyataan bahwa algoritma VNS-HC hanya kalah pada problem domain TSP ini menarik untuk diinvestigasi pada penelitian berikutnya. Hal ini mungkin disebabkan struktur permasalahan TSP yang berbeda dari permasalahan yang lainya. Selain itu penggunaan algoritma Hill Climbing sebagai strategi move acceptance pada literatur terdahulu diketahui memang memiliki performa yang buruk, yaitu mudah terjebak pada lokal optima. Oleh karena itu pada penelitian selanjutnya algoritma VNS ini perlu digabungkan dengan algoritma yang lebih robust, sehingga dihasilkan performa algoritma yang lebih baik.

\section{Daftar Pustaka}

[1] R. Qu, "Meta-heurisitic Algorithm," University of Nottingham, Apr-2016. [Online]. Available: http://www.cs.nott.ac.uk/ pszrq.

[2] E. K. Burke, Search methodologies. New York: Springer, 2013.

[3] G. Ochoa, "Search-based Approaches and Hyper-heuristics."
[4] E. K. Burke, M. Hyde, G. Kendall, G. Ochoa, E. Özcan, and J. R. Woodward, "A classification of hyper-heuristic approaches," in Handbook of metaheuristics, Springer, 2010, pp. 449-468.

[5] E. K. Burke et al., "Hyper-heuristics: a survey of the state of the art," J. Oper. Res. Soc., vol. 64, no. 12, pp. 1695-1724, Dec. 2013.

[6] S. S. Choong, L.-P. Wong, and C. P. Lim, "Automatic design of hyper-heuristic based on reinforcement learning," Inf. Sci., vol. 436-437, pp. 89-107, Apr. 2018.

[7] M. Misir, W. Vancroonenburg, K. Verbeeck, and G. V. Berghe, "A selection hyper-heuristic for scheduling deliveries of ready-mixed concrete," p. $11,2011$.

[8] W. G. Jackson, E. Ozcan, and J. H. Drake, "Late acceptance-based selection hyper-heuristics for cross-domain heuristic search," 2013, pp. 228235.

[9] P. Hansen and N. Mladenović, "Variable neighborhood search: Principles and applications," Eur. J. Oper. Res., vol. 130, no. 3, pp. 449-467, 2001.

[10] Z. Xu and Y. Cai, "Variable neighborhood search for consistent vehicle routing problem," Expert Syst. Appl., vol. 113, pp. 66-76, Dec. 2018.

[11] Y. Qiu, L. Wang, X. Xu, X. Fang, and P. M. Pardalos, "A variable neighborhood search heuristic algorithm for production routing problems," Appl. Soft Comput., vol. 66, pp. 311-318, May 2018.

[12] T. Czachórski, E. Gelenbe, K. Grochla, and R. Lent, Eds., "Performance of Selection Hyper-heuristics on the Extended HyFlex Domains," vol. 659, 2016.

[13] G. Ochoa et al., "Hyflex: A benchmark framework for cross-domain heuristic search," in European Conference on Evolutionary Computation in Combinatorial Optimization, 2012, pp. 136-147.

[14] N. D. Angresti, A. Djunaidy, and A. Mukhlason, "Penerapan Hiperheuristik Berbasis Metode Simulated Penyelesaian Permasalahan Optimasi Lintas Domain," vol. 05, no. 01, p. 8, 2019.

[15] N. R. Sabar, M. Ayob, G. Kendall, and Rong Qu, "A Dynamic Multiarmed Bandit-Gene Expression Programming Hyper-Heuristic for Combinatorial Optimization Problems," IEEE Trans. Cybern., vol. 45, no. 2, pp. 217-228, Feb. 2015.

[16] A. Muklason, A. J. Parkes, E. Özcan, B. McCollum, and P. McMullan, "Fairness in examination timetabling: Student preferences and extended formulations," Appl. Soft Comput., vol. 55, pp. 302-318, Jun. 2017.

[17] A. Muklason and A. J. Parkes, "Hyper-heuristics for Solving a Multi-objective Examination Timetabling Problem," PATAT 2018 Proc. 12th Int. Conf. Pract. Theory Autom. Timetabling, p. 1, 2018. 